\title{
NIERZETELNY MARKETING EKOLOGICZNY (GREENWASHING) - OPIS ZJAWISKA I PRÓBA JEGO KWALIFIKACJI PRAWNEJ
}

\section{GREENWASHING - DESCRIPTION OF THE PHENOMENON AND ATTEMPT TOWARDS ITS LEGAL QUALIFICATION}

http://dx.doi.org/10.12775/PPOS.2015.023

\section{STRESZCZENIE}

Celem opracowania jest omówienie problematyki nierzetelnego marketingu ekologicznego (ang. greenwashing). Mianem tym określany jest marketing wprowadzający odbiorców w błąd w odniesieniu do praktyk ekologicznych przedsiębiorcy lub korzyści ekologicznych jego

" Magister prawa, aplikant rzecznikowski. 
produktu albo usługi. W pracy przedstawiono typologię tego zjawiska zaproponowaną przez TerraChoice Inc. oraz podjęto próbę jego subsumpcji do norm prawa konkurencji i norm prawnych dotyczących rolnictwa ekologicznego. W ocenie tej wzięto pod uwagę dorobek orzeczniczy krajów skandynawskich, które świadomie walczą z wszelkimi formami nieuczciwej reklamy ekologicznej. W pracy wskazano także źródła „soft law”, które doprecyzowują nieostre pojęcia norm prawa powszechnie obowiązującego.

\section{Słowa kluczowe}

Nierzetelny marketing ekologiczny; greenwashing; nieuczciwa konkurencja; nieuczciwe praktyki handlowe; rolnictwo ekologiczne.

\section{ABSTRACT}

The goal of this article was to describe the phenomenon of the "greenwashing" - unfair marketing behavior, which deceives consumers in relation to a trader's ecological practices or ecological benefits of his goods or services. This work presents a typology of this phenomenon as proposed by TerraChoice Inc. Moreover, an attempt towards its legal qualification to the norms of competition law and norms relating to organic production has been undertaken. This analysis was supported by the study of judiciary decisions of Scandinavian countries, which consciously oppose against any forms of unfair ecological advertisement. This article also presents also the sources of soft law in which the vague definitions of the universally binding law have been specified.

\section{Keywords}

Unfair green marketing; greenwashing; unfair competition; unfair commercial practices; organic production.

\section{UWAGI WSTĘPNE}

Począwszy od końca lat sześćdziesiątych ubiegłego wieku wzrasta na świecie zainteresowanie zagadnieniami zrównowa- 
żonego rozwoju i ekologii ${ }^{1}$. Przedsiębiorcy ustosunkowują się do zwiększającej się świadomości konsumentów w tym zakresie w dwójnasób - poprzez działania rzeczywiście pozytywnie wpływające na stan środowiska oraz poprzez zabiegi realizowane wyłącznie w sferze językowej. Z perspektywy analizowanego w niniejszym opracowaniu problemu nierzetelnego marketingu ekologicznego szczególne znaczenie ma ta druga grupa zachowań.

Poniżej podjęto próbę zdefiniowania przedmiotowego zjawiska oraz jego oceny na gruncie obowiązujących przepisów. Dla jego pełnego zrozumienia wskazana może być także ocena rozwiązań amerykańskich, które jednak nie są przedmiotem niniejszego opracowania ${ }^{2}$.

\section{OPIS ZJAWISKA NIERZETELNEGO MARKETINGU EKOLOGICZNEGO}

Nierzetelny marketing ekologiczny to marketing wprowadzający odbiorców w błąd w odniesieniu do praktyk ekologicznych przedsiębiorcy lub korzyści ekologicznych jego produktu lub usługi.

Kanadyjska spółka TerraChoice Environmental Marketing Inc. w swoim raporcie z 2007 roku i jego późniejszych reedycjach z lat 2009 i 2010 dokonała typologii nierzetelnego marketingu ekologicznego ${ }^{3}$. Raporty te do dzisiaj stanowią istotny punkt odniesienia dla oceny opisywanego zjawiska. Wyróżniono w nich następujące zachowania:

a) ukrycie kosztu alternatywnego (Sin of the Hidden Trade-Off) - przekaz, w którym sugeruje się ekologiczne

1 Por. B. Pilarczyk, R. Nestorowicz, Marketing ekologicznych produktów żywnościowych, Warszawa 2010, s. 14.

2 Szerzej na ten temat: I. Nestoruk, Greenwashing, czyli nierzetelny marketing ekologiczny $w$ prawie amerykańskim, „Radca Prawny” 2011, nr 7-8, s. 9.

3 Environmental Marketing, The Six Sins of Greenwashing: A Study of Environmental Claims in North American Consumer Markets (2007), http://sinsofgreenwashing.org/ [dostęp: 26.02.2015 r.] 
właściwości produktu lub usługi w oparciu o jedną tylko jego cechę lub wąski zespół cech, wyróżnionych w sztuczny sposób, ignorując inne istotne właściwości danego produktu lub danej usługi;

b) brak dowodu (Sin of No Proof) - deklaracje, które nie znajdują poparcia w łatwo dostępnych materiałach albo w gwarancjach renomowanych organizacji;

c) brak precyzji (Sin of Vagueness) - deklaracje, w których używa się określeń tak szerokich lub nieprecyzyjnych, że w rzeczywistości mogą one wprowadzać odbiorcę w błąd;

d) podkreślenie cech nieistotnych (Sin of Irrelevance) - deklaracje, w których sugeruje się ekologiczne właściwości produktu lub usługi w oparciu o jedną tylko cechę lub wąski zespół cech wyróżnionych w sztuczny sposób, ignorując inne istotne właściwości danego produktu lub danej usługi;

e) promocja mniejszego zła (Sin of Lesser of Two Evils) podkreślanie ekologicznych właściwości danego produktu lub usługi należących do kategorii, która jako całość ma zdecydowanie negatywny wpływ na środowisko;

f) kłamstwo (Sin of Fibbing);

g) posługiwanie się fałszywymi ekoetykietami (Sin of Worshiping False Labels) - tworzenie i używanie własnych etykiet odnoszących się do ekologii i opatrywanie nimi produktów w taki sposób, że odbiorca odnosi wrażenie, że dany produkt jest certyfikowany przez podmiot zewnętrzny. 


\section{GREENWASHING W ZAŁOŻENIACH PROGRAMOWYCH UNII EUROPEJSKIEJ}

Do analizowanego problemu odnosi się tzW. „Europejski program na rzecz konsumentów"4. Jak zauważają jego autorzy, jeżeli konsumenci mają mieć odpowiednio silną pozycję, muszą posiadać jasne, wiarygodne i porównywalne informacje, a także muszą być w stanie je zrozumieć. Jest to szczególnie istotne w świetle zwiększającej się ilości informacji przetwarzanych w społeczeństwie cyfrowym, co nie zawsze przekłada się na zwiększenie poziomu wiedzy odbiorców. Tak zwana strategia ochrony przez informację znajduje się także u podstaw aksjologicznych polskiego systemu prawa ochrony konsumenta ${ }^{5}$.

Wzrost globalnej konsumpcji zwiększa presję na środowisko naturalne ${ }^{6}$. Powoduje to konieczność uwzględniania tego zjawiska w planach rozwoju gospodarczego społeczeństw. Stąd też w założeniach „Europejskiego programu na rzecz konsumentów" widać wyraźną tendencję do wspierania ruchów zmierzających do zwiększenia świadomości ekologicznej obywateli Unii Europejskiej oraz do zachęcania ich, aby świadomość tę wykorzystywali w swoich decyzjach zakupowych. Jak wskazuje Komisja Europejska, potrzebne są skuteczne narzędzia, które będą chronić konsumentów przed wprowadzającymi w błąd i bezzasadnymi deklaracjami dotyczącymi ekologiczności produktu. Konsumenci mają ponadto prawo do tego, by dowiedzieć się, jaki wpływ na środowisko wywierają produkty, które zamie-

4 Komunikat Komisji do Parlamentu Europejskiego, Rady, Europejskiego Komitetu Ekonomiczno-Społecznego i Komitetu Regionów - Europejski program na rzecz konsumentów - Zwiększanie zaufania i pobudzanie wzrostu gospodarczego z dnia 22 maja 2012 r. KOM (2012) 225 final.

5 Por. Wyrok TK z dnia 26 stycznia 2005 r., sygn. P 10/04 (OTK-A 2005, nr 1, poz. 7).

6 Por. Komunikat Komisji do Parlamentu Europejskiego, Rady, Europejskiego Komitetu Ekonomiczno-społecznego i Komitetu Regionów - Plan działania na rzecz zasobooszczędnej Europy z dnia 22 września 2011 roku, KOM (2011) 571 final. 
rzają kupić i usługi, z których zamierzają skorzystać ${ }^{7}$. Informacje na temat tego wpływu powinny dotyczyć całego cyklu życia danego produktu ${ }^{8}$, a nie tylko wybranych okresów jego trwania. Aby oczekiwania te zostały spełnione, należy dbać o to, żeby deklaracje dotyczące ochrony środowiska były jasne, ścisłe i uzasadnione, umożliwiające konsumentom dokonywanie świadomych i logicznych wyborów ${ }^{9}$. Deklaracje takie nie mogą ukrywać kosztów alternatywnych ${ }^{10}$.

\section{GREENWASHING A AKTY PRAWNE DOTYCZĄCE ROLNICTWA EKOLOGICZNEGO}

Aktem prawnym próbującym w sposób najbardziej zdecydowany zmierzyć się z problemem nierzetelnego marketingu ekologicznego jest bezpośrednio stosowane Rozporządzenie Rady nr 834/2007 w sprawie produkcji ekologicznej i znakowania produktów ekologicznych ${ }^{11}$. W motywie 23 preambuły tego aktu prawnego wskazano, że terminy używane do oznaczania produktów rolnictwa ekologicznego powinny podlegać ochronie, tak aby nie mogły być używane do oznaczania produktów nieekologicznych w obrębie Unii Europejskiej - założenie to realizują przepisy zawarte w tytule IV tego aktu prawnego. Dotyczą one bardzo szerokiej grupy określeń. Jak wynika z art. 23 ust. 1 Rozporządzenia 834/2007, uznaje się, że produkt opa-

7 Ibidem, s. 5.

8 Więcej na temat cyklu życia: I. Sousa, D. Wallace, N. Borland, J. Deniz, A learning surrogate LCA model for integrated product design, Massachusetts 1999, http://cadlab.mit.edu/publications/99-sousa-lifecycle/dontindex/lifecycle.pdf.

9 Dokument roboczy służby Komisji - Wytyczne w sprawie wdrożenia/ wykonania Dyrektywy 2005/29/WE z dnia 3 grudnia 2009 r. SEC (2009) 1666, s. 4.

10 Ibidem, s. 40.

11 Rozporządzenie Rady nr 834/2007 z dnia 28 czerwca 2007 r. w sprawie produkcji ekologicznej i znakowania produktów ekologicznych, Dz. Urz. UE L 189 z 20.07.2007 r., s. 1, dalej cyt.: Rozporządzenie 834/2007. 
trzony jest terminem odnoszącym się do ekologicznej metody produkcji, jeżeli przy znakowaniu, w materiałach reklamowych lub dokumentach handlowych taki produkt, jego składniki lub materiały paszowe opisywane są za pomocą terminów sugerujących nabywcy, że produkt ten, jego składniki lub materiały paszowe zostały uzyskane zgodnie z przepisami określonymi w tym rozporządzeniu. Dotyczy to w szczególności słów „ekologiczny”, „eko”, „bio” i ich pochodnych. Należy zwrócić uwagę na fakt, że przepis ten odnosi się nie tylko do wyrażeń wskazanych w nim wprost, ale do wszelkich określeń, które chociażby sugerują (ang. suggesting), że zastosowana metoda produkcji jest zgodna z Rozporządzeniem 834/2007, a więc, że jest rzeczywiście ekologiczna. W żadnym z języków Unii Europejskiej i na całym jej terenie nie dopuszcza się stosowania tego typu wyrażeń w znakowaniu, reklamie i dokumentach handlowych produktu, który nie spełnia wymogów wymienionych w tym rozporządzeniu, chyba że nie są one używane w odniesieniu do produktów rolnych w żywności lub paszy albo wyraźnie w żaden sposób nie łączą się z produkcją ekologiczną. W zakresie tego przepisu mieści się także używanie opisanych terminów w znakach towarowych ${ }^{12}$, wzorach przemysłowych, jak również w nazwie przedsiębiorstwa $^{13}$, o ile nazwa ta pojawia się $\mathrm{w}$ „znakowaniu, reklamie lub dokumentach handlowych"14. Przywołany przepis zawiera także generalny zakaz stosowania jakichkolwiek terminów i praktyk używanych w znakowaniu lub reklamie, mogących wprowadzić w błąd konsumenta albo użytkownika, poprzez sugerowanie, że produkt lub jego składniki spełniają wymogi wymienione $\mathrm{w}$ analizowanym rozporządzeniu. Niedopuszczalne jest stosowanie opisanych wyżej terminów w od-

12 Por. np. Wyrok WSA w Warszawie z dnia 8 sierpnia 2013 r., VISA/Wa 175/13 (CBOSA) lubWyrokWSA w Warszawie z dnia 8 sierpnia 2013 r., VI SA/Wa 174/13 (CBOSA).

13 Por. Wyroki WSA w Warszawie: z dnia 27 września 2012 r., VI SA/Wa 1251/12; z dnia 27 września 2012 r., VI SA/Wa 1254/12 i z dnia 27 września 2012 r., VI SA/Wa 1255/12 (CBOSA).

14 Pojęcia te były (dość pobieżnie) analizowane były przez WSA w Warszawie w Wyrokach z dnia 8 sierpnia 2013 r., VI SA/Wa 174/13 oraz VI SA/Wa 175/13 (CBOSA). 
niesieniu do żywności przetworzonej, w której składniki ekologiczne nie stanowią przynajmniej 95\% jej masy ${ }^{15}$. Zakazane jest także stosowanie wyżej wymienionych terminów w odniesieniu do jakichkolwiek produktów, w których zastosowano organizmy zmodyfikowane genetycznie ${ }^{16}$.

Zapewnienie zgodności zachowań przedsiębiorców z przepisami Rozporządzenia 834/2007 zostało na mocy art. 23 ust. 5 przeniesione na państwa członkowskie. Polska realizuje ten obowiązek poprzez Ustawę o rolnictwie ekologicznym ${ }^{17}$, określającą procedury egzekwowania obowiązków określonych w przedmiotowym rozporządzeniu. Zgodnie z art. 25 ust. 1 pkt 5 lit. b tej ustawy osoba fizyczna, osoba prawna lub jednostka organizacyjna nieposiadająca osobowości prawnej, która wprowadza do obrotu produkt, który został oznakowany jako produkt rolnictwa ekologicznego z naruszeniem art. 23-26 Rozporządzenia 834/2007, podlega karze pieniężnej w wysokości do 200\% korzyści majątkowej uzyskanej lub którą mogłaby uzyskać za wprowadzone do obrotu produktu, nie niższej jednak niż 500 zł. Na podstawie art. 35 ust. 4 tej ustawy karę tę wymierza Główny Inspektor Jakości Handlowej Artykułów Rolno-Spożywczych.

\section{GREENWASHING A AKTY PRAWNE DOTYCZĄCE PRZECIWDZIAŁANIA NIEUCZCIWYM PRAKTYKOM HANDLOWYM ORAZ ZWALCZANIA NIEUCZCIWEJ KONKURENCJI}

$\mathrm{U}$ podstaw przepisów dotyczących walki z nieuczciwą reklamą sensu largo jest założenie, że warunkiem koniecznym funkcjonowania gospodarki rynkowej powinna być dopuszczalność wszystkich stosowanych przez przedsiębiorców uczciwych

15 Art. 23 ust. 4 lit a pkt II Rozporządzenia 834/2007.

16 Art. 23 ust. 3 lit a pkt II Rozporządzenia 834/2007.

17 Ustawa z dnia 25 czerwca 2009 r. o rolnictwie ekologicznym, t.j. Dz.U. z 2015 r., poz. 497. 
form pozyskiwania klienteli, przy jednoczesnej walce z działaniami, które byłyby sprzeczne z prawem lub dobrymi obyczajami. Zachowania takie zafałszowują obraz rynku, czym naruszają interes publiczny $\mathrm{w}$ zachowaniu konkurencji, zmieniając „atmosferę" w jakiej prowadzona jest działalność gospodarcza ${ }^{18}$. Greenwashing przekłada się na cynizm odbiorców, którzy tracą zaufanie do wszelkiego rodzaju deklaracji dotyczących ochrony środowiska naturalnego. Niektóre przypadki tego zjawiska mogą więc wypełniać dyspozycje norm dotyczących zwalczania nieuczciwych praktyk handlowych, nielegalnej konkurencji i zachowań naruszających zbiorowe interesu konsumentów.

Zgodnie z art. 6 Ustawy z dnia 23 sierpnia 2007 r. o przeciwdziałaniu nieuczciwym praktykom rynkowym ${ }^{19}$ praktykę rynkową uznaje się za zaniechanie wprowadzające w błąd, jeżeli pomija ona istotne informacje potrzebne przeciętnemu konsumentowi do podjęcia świadomej decyzji dotyczącej transakcji i tym samym powoduje lub może powodować podjęcie przez niego takiej decyzji, której w innym przypadku by nie podjął. W ocenie zachowań przedsiębiorcy bierze się pod uwagę wszystkie cechy jego praktyki, okoliczności oraz ograniczenia środka przekazu. Zgodnie z ustępem trzecim tego artykułu za wprowadzające $\mathrm{w}$ błąd uznaje się w szczególności zatajenie lub przekazanie w sposób niejasny, niezrozumiały, dwuznaczny lub z opóźnieniem istotnych informacji dotyczących produktu. Przepis ten, odwołując się do pojęcia niejasności i dwuznaczności, stanowi silne narzędzie walki z opisywanym zjawiskiem.

Zgodnie $\mathrm{z}$ art. 5 ust. 1 u.p.n.p.r. praktykę handlową uznaje się za działanie wprowadzające w błąd, jeżeli wprowadza lub może wprowadzić w błąd przeciętnego konsumenta i przy tym powoduje ona lub może spowodować podjęcie przez konsumenta decyzji dotyczącej transakcji, której inaczej by nie podjął. Należy mieć na uwadze, że formalna prawdziwość informacji

18 Tischner A., w: Prawo konkurencji, t. 15: System Prawa Prywatnego, red. M. Kępiński, Warszawa 2014, s. 101.

19 Ustawa z dnia 23 sierpnia 2007 r. o przeciwdziałaniu nieuczciwym praktykom rynkowym, Dz.U. z 2007 r. nr 171, poz. 1206 ze zm., dalej cyt.: u.p.n.p.r. 
nie wyłącza zastosowania przywołanego przepisu. W szczególności podkreślenie unikalnych właściwości produktu, którego dotyczy przekaz, w sytuacji gdy konkurencyjne towary tego samego rodzaju posiadają te same cechy, uważany jest często za praktykę wprowadzającą w błąd ${ }^{20}$. Ponadto norma ta może znaleźć zastosowanie do każdej formy prezentacji informacji w tym formy słownej, słowno-graficznej lub graficznej. Obejmuje to także stosowanie zarejestrowanego znaku towarowego lub wzoru przemysłowego.

Na podstawie ww. przepisów wyróżnia się dwa typy zakazanych praktyk wprowadzających w błąd:

1) praktyki obiektywnie wprowadzające w błąd - chodzi tu o oświadczenia mające postać zdania logicznego, któremu można przypisać wartość „fałsz”;

2) praktyki subiektywnie wprowadzające w błąd - są to deklaracje, które nie muszą być zdaniami w sensie logicznym (w szczególności mogą to być elementy graficzne), a jeżeli są one zdaniami, to nie muszą być one fałszywe $\mathrm{w}$ sensie logicznym, a mimo tego wywołują one pomyłkę przeciętnego konsumenta lub mogą one do takiej pomyłki doprowadzić. W ocenie tego typu praktyk szczególnie ważne jest branie pod uwagę całego kontekstu przedstawienia informacji.

Szczególnie ta druga grupa zachowań wiąże się z analizowaną problematyką nierzetelnego marketingu ekologicznego.

Praktyka handlowa - aby mogła zostać uznana za nieuczciwą - musi być sprzeczna z zasadami staranności zawodowej, a także musi być zdolna zakłócić decyzję przeciętnego konsumenta dotyczącą transakcji. Ograniczenie to nie dotyczy zachowań, które zostały wprost wyliczone w „czarnej liście” przedstawionej $\mathrm{w}$ art. 7 u.p.n.p.r. W kontekście nierzetelnego marketingu ekologicznego szczególne znaczenie mają następujące, zawarte w tej liście, zachowania:

20 Por. M. Kępiński, I. Wiszniewska, w: Ustawa o zwalczaniu nieuczciwej konkurencji - Komentarz, red. J. Szwaja, Warszawa 2013, s. 37. 
1) podawanie się przez przedsiębiorcę za sygnatariusza kodeksu dobrych praktyk, gdy jest to niezgodne z rzeczywistością;

2) posługiwanie się certyfikatem, znakiem jakości lub równorzędnym oznaczeniem, nie mając do tego uprawnienia;

3) twierdzenie, że kodeks dobrych praktyk został zatwierdzony przez organ publiczny lub inny organ, jeżeli jest to niezgodne z prawdą;

4) twierdzenie, że przedsiębiorca uzyskał stosowne uprawnienie od organu publicznego lub podmiotu prywatnego,

5) twierdzenie, że praktyki rynkowe lub produkt zostały zatwierdzone, zaaprobowane lub uzyskały inne stosowne uprawnienie od organu publicznego lub podmiotu prywatnego.

Ustawa ta musi być interpretowana w zgodzie z Dyrektywą 2005/29/WE ${ }^{21}$. W wytycznych w sprawie wdrożenia i wykonania tej dyrektywy sformułowano dwie ogólne zasady dotyczące wprost nierzetelnego marketingu ekologicznego:

1) przedsiębiorcy muszą przede wszystkim przedstawić swoje deklaracje ekologiczne w sposób szczegółowy, dokładny i jednoznaczny, aby wyłączony został zarzut popełnienia praktyki polegającej na zaniechaniu wprowadzającym w błąd;

2) przedsiębiorcy muszą mieć dowody na poparcie swoich deklaracji i muszą być gotowi przedstawić te dowody w zrozumiały sposób, jeżeli ich deklaracja zostanie zakwestionowana.

W praktyce w gospodarce rynkowej marginalny charakter mają zachowania przedsiębiorców, w których dochodzi wy-

21 Dyrektywa 2005/29/WE Parlamentu Europejskiego i Rady z dnia 11 maja 2005 r. dotycząca nieuczciwych praktyk handlowych stosowanych przez przedsiębiorstwa wobec konsumentów na rynku wewnętrznym oraz zmieniająca Dyrektywę Rady 84/450/EWG, Dyrektywy 97/7/WE, 98/27/WE i 2002/65/WE Parlamentu Europejskiego i Rady oraz Rozporządzenie (WE) nr 2006/2004 Parlamentu Europejskiego i Rady („Dyrektywa o nieuczciwych praktykach handlowych"), Dz. Urz. UE L 149 z 11.6.2005, s. 22. 
łącznie do naruszenia interesów nabywców towarów lub usług. Nieuczciwe działania marketingowe, godząc w interesy konsumentów, zwykle naruszają też interesy innych przedsiębiorców $^{22}$. W związku z tym nie można bagatelizować roli przepisów o zwalczaniu nieuczciwej konkurencji w kształtowaniu uczciwych zasad gospodarki rynkowej. Celem Ustawy z dnia 16 kwietnia 1993 r. o zwalczaniu nieuczciwej konkurencji ${ }^{23}$ jest zapobieganie i zwalczanie nieuczciwej konkurencji w działalności gospodarczej - w interesie publicznym, przedsiębiorców oraz klientów. Ustawa ta, podobnie jak analizowana wcześniej Ustawa o przeciwdziałaniu nieuczciwym praktykom rynkowym, należy systemowo do prawa prywatnego regulującego uczciwość obrotu - stąd też wykładnia tych aktów prawnych powinna być spójna.

Wyrażona w art. 3 ust. 1 u.z.n.k. klauzula generalna nakazuje objąć jej zastosowaniem wszelkie działania sprzeczne z prawem lub dobrymi obyczajami, które zagrażają lub naruszają interes innego przedsiębiorcy albo klienta. Do szczególnych przypadków nieuczciwej konkurencji należy wprowadzające w błąd oznaczanie towarów lub usług (art. 10 u.z.n.k.) oraz reklama wprowadzająca klienta w błąd i mogąca przez to wpłynąć na jego decyzję co do nabycia towaru lub usługi (art. 16 ust. 1 pkt 2 u.z.n.k.). W zakresie zastosowania tych przepisów mieści się także używanie oznaczeń mogących mylić nabywcę, nawet jeśli oznaczenia te nie są fałszywe w sensie logicznym. Chodzi tu o oznaczenia, które nabywca odbiera niewłaściwie, które są dwuznaczne, niepełne lub niejasne ${ }^{24}$. Dotyczy to także używania w odniesieniu do produktów lub usług informacji prawdziwych, wywołujących mylącą sugestię, że ich przywoływane cechy są wyjątkowe ${ }^{25}$. Jako przykłady reklamy spełniającej dyspozycję normy wyrażonej w art. 16 u.z.n.k. podaje się:

22 Por. R. Skubisz, op. cit., s. 388.

23 Ustawa z dnia 16 kwietnia 1993 r. o zwalczaniu nieuczciwej konkurencji, t.j. Dz.U. z 2003 r. nr 153, poz. 1503 ze zm., dalej cyt.: u.z.n.k.

24 Wyrok SA w Krakowie z dnia 24 października 2012 r. I ACa 831/12 (CBOSA).

25 M. Kępiński, J. Kępiński, I. Wiszniewska, w: op. cit., s. 376. 
reklamę niepełną, reklamę niejasną i reklamę z oczywistościa$\mathrm{mi}^{26}$.

Kolejnym narzędziem prawnym gwarantującym uczciwość obrotu jest Ustawa z dnia 16 lutego 2007 r. o ochronie konkurencji i konsumentów ${ }^{27}$. Ustawa ta umożliwia wszczęcie przez Prezesa Urzędu Ochrony Konkurencji i Konsumentów postępowania administracyjnego w sprawie praktyki naruszającej zbiorowe interesy konsumentów. Postępowaniem takim może być objęte zachowanie będące nieuczciwą praktyką rynkową lub czynem nieuczciwej konkurencji, jak również naruszenie obowiązku udzielania konsumentom rzetelnej, prawdziwej i pełnej informacji. Na nieuczciwego przedsiębiorcę może być nałożona kara pieniężna w wysokości do $10 \%$ przychodu osiągniętego w roku rozliczeniowym, poprzedzającym rok nałożenia kary (art. 106 ust. 1 pkt 4 tej ustawy).

Spośród bardzo ubogiego dorobku polskiej judykatury na uwagę zasługuje Wyrok Sądu Apelacyjnego w Warszawie z dnia 21 grudnia 2006 r., w którym potwierdzono że używanie przez pozwanego oznaczenia „z naturalnymi stanolami roślinnymi” na opakowaniu produktu, w którym zawartość przedmiotowych stanoli była minimalna, może powodować wprowadzenie w błąd klientów co do jego składników.

Dużo więcej materiałów do prawnej analizy problematyki nierzetelnego marketingu ekologicznego dostarcza orzecznictwo sądów innych krajów Unii Europejskiej - w szczególności sądów krajów skandynawskich. W licznych wyrokach można wyodrębnić następujące tezy:

- porównanie wpływu produktów na środowisko bez uwzględnienia całego „cyklu życia produktu” stanowić może zakazaną reklamę porównawczą ${ }^{28}$ lub nieuczciwą

26 Ibidem, s. 464.

27 Ustawa z dnia 16 lutego 2007 r. o ochronie konkurencji i konsumentów, t.j. Dz.U. z 2014 r., poz. 945 ze zm.

28 Wyrok szwedzkiego sądu gospodarczego (Marknadsdomstolen) z 1989 r., sygn. MD 1989:2 przywoływany za: E. Sjöström, S. Sweet, J. Ählström, Marknadskommunikation och hållbar utveckling, Sztokholm 2005, s. 53, http://www.naturvardsverket.se/Nerladdningssida/?fileType=pdf\&downloadUrl=/Documents/publikationer/620-5522-4.pdf [dostęp: 26.02.2015r.] 
praktykę handlową będącą działaniem wprowadzającym w błąd ${ }^{29}$;

- podkreślanie w reklamie produktu braku w jego składzie szkodliwej substancji przy obecności innych substancji negatywnie wpływających na środowisko stanowić może działanie wprowadzające w błąd ${ }^{30}$;

- używanie ogólnych określeń, takich jak „przyjazny środowisku" wymagać powinno udostępnienia dodatkowych materiałów lub wyjaśnień doprecyzowujących to wyrażenie, w przeciwnym wypadku może zostać uznane za działanie wprowadzające $\mathrm{w}$ błąd ${ }^{31}$.

Trudno odmówić słuszności tym tezom także na gruncie polskich przepisów.

\section{NIERZETELNY MARKETING EKOLOGICZNYCH W NORMACH SOFT LAW}

Zjawisko nierzetelnego marketingu ekologicznego zostało szczegółowo opisane i stypizowane w licznych aktach normatywnych typu „soft law”. Prócz cytowanych wcześniej dokumentów programowych Unii Europejskiej na szczególną uwagę za-

oraz Wyrok Sądu Morskiego i Gospodarczego w Kopenhadze z dnia 30 grudnia 2011 r., sygn. H-0009-10.

29 Opinia duńskiego rzecznika praw konsumenta w sprawie o sygnaturze 08/02992 opisana w komunikacie prasowym, http://www.forbrugerombudsmanden.dk/Sager-og-praksis/Markedsfoeringsloven/Sager-efter-markedsfoeringsloven/miljoeogetik/groenmarkedsf.

30 Wyrok szwedzkiego sądu gospodarczego z 1990 r., sygn. MD 1990:20, przywoływany za: E. Sjöström, S. Sweet, J. Ählström, op. cit., s. 54.

31 Wyrok szwedzkiego sądu gospodarczego z dnia 31 maja 2011 r. sygn. MD 2011:12, przywołany za: K. Strömholm, C. Blomhammar Sandberg, Intellectual Property Rigths - Yearbook 2012, Sztokholm 2012, s. 123, http:// www.lindahl.se/media/488464/lindahl_intellectual_property_rights_yearbook_2011.pdf. 
sługują: Kodeks Etyki Reklamy, wytyczne Międzynarodowej Izby Handlowej $^{32}$, wytyczne OECD ${ }^{33}$ i treść normy ISO 14021:1999.

Wydaje się, że dla polskich przedsiębiorców największe znaczenie praktyczne mogą mieć normy Kodeksu Etyki Reklamy, który stanowi wyraz samoregulacji polskiej branży reklamowej. Uchwała ta w artykułach 33-39 odnosi się wprost do problemu nierzetelnej reklamy ekologicznej. Jedyna jak do tej pory sprawa, w której stwierdzone zostało naruszenie wskazanych przepisów dotyczyła reklamy prasowej jednego z dostawców energii elektrycznej, zawierającej hasła i obrazy stanowiące deklaracje pośrednio wskazujące na pozytywny wpływ jego działalności na środowisko naturalne ${ }^{34}$. W reklamie tej wykorzystano sformułowania „Czysta energia. Czysty biznes” oraz „Potęga wiatru. Siła wody. Korzystamy z natury, by dać Ci czystą energię”, podczas gdy odnawialne źródła energii dostarczały wówczas niewiele ponad 5\% oferowanej przez ten podmiot mocy. Komisja etyki reklamy zwróciła uwagę na możliwość wprowadzenia w błąd poprzez przekaz, w którym jedynie w pośredni sposób sugeruje się pewne właściwości towarów lub usług. Zdaniem zespołu orzekającego w ocenie takiego przekazu należy brać pod uwagę wszystkie towarzyszące mu okoliczności.

\section{WNIOSKI}

Stosunkowo nowe dla polskiego przedsiębiorcy i konsumenta zjawisko nierzetelnego marketingu ekologicznego okazuje się być dość szczelnie objęte regulacją norm prawa kra-

32 Dokument Międzynarodowej Izby Handlowej nr 240-46/665, Framework for Responsible Environmental Marketing Communications, International Chamber of Commerce, 2011, http://www.iccwbo.org/Data/Policies/2011/ Framework-for-Environmental-Claims-July-2011/ [dostęp: 26.02.2015 r.]

33 Dokument OECD DSTI/CP(2010)16/FINAL z marca 2011 r., Environmental Claims Findings and Conclusions of the OECD Committee on Consumer Policy, http://www.oecd.org/sti/consumer/48127506.pdf. [dostęp: 26.02.2015 r.]

34 Uchwała Komisji Etyki Reklamy nr ZO 45/10 z dnia 8 lipca 2010 r., sygn. K/58/101. 
jowego i unijnego. W obowiązującym prawie trudno znaleźć istotne luki, niemniej jednak przepisy regulujące tę materię zawierają wiele wyrażeń ogólnych i nieprecyzyjnych. W dużej mierze było to intencją ustawodawcy - szczególnie w odniesieniu do aktów prawnych dotyczących zwalczania nieuczciwej konkurencji i przeciwdziałaniu nieuczciwym praktykom handlowym. Rodzi to jednak niepewność co do treści obowiązującego prawa w odniesieniu do stosunkowo nowego zjawiska nierzetelnego marketingu ekologicznego i może być wyzwaniem dla podmiotów je stosujących. Istotne wskazówki interpretacyjne można jednak znaleźć $\mathrm{w}$ aktach normatywnych, które w sposób bardziej skonkretyzowany odnoszą się do analizowanego problemu, takich jak: Kodeks Etyki Reklamy, wytyczne Międzynarodowej Izby Handlowej, wytyczne OECD, norma ISO 14021:1999, a także w wytycznych w sprawie wdrożenia/ wykonania Dyrektywy 2005/29/WE oraz w dokumentach programowych Unii Europejskiej, w szczególności w „Europejskim programie na rzecz konsumentów".

\section{BIBLIOGRAFIA}

Nestoruk I., Greenwashing, czyli nierzetelny marketing ekologiczny w prawie amerykańskim, „Radca Prawny” 2011, nr 7-8.

Pilarczyk B., Nestorowicz R., Marketing ekologicznych produktów żywnościowych, Warszawa 2010.

Prawo konkurencji, tom 15, System Prawa Prywatnego, red. M. Kępiński, Warszawa 2014.

Sjöström E., Sweet S., Ählström J., Marknadskommunikation och hållbar utveckling, Sztokholm 2005.

Sousa I., Wallace D., Borland N., Deniz J., A learning surrogate LCA model for integrated product design, Massachusetts 1999.

Strömholm K., Blomhammar Sandberg C., Intellectual Property Rigths - Yearbook 2012, Sztokholm 2012.

Ustawa o zwalczaniu nieuczciwej konkurencji - Komentarz, red. J. Szwaja, Warszawa 2013.

Kontakt e-mail:

2/2015 bartosz.fert@gmail.com 